\title{
Radicalism and Intolerance in Padang City
}

\author{
Muhammad Faisal Hamdani ${ }^{1}$, Eldin Zainal $^{2}$ \\ ${ }^{1,2}$ Universitas Islam Negeri Sumatera Utara, Indonesia \\ hamdanim1014@gmail.com
}

\begin{abstract}
Padang is a unique city because its people have the principle of making their customs code syara 'and syara' coded as Kitabullah in everyday life. This principle has always been the motivation to act and it is not uncommon for some Padang people to be accused of radicalism and intolerance. This article explores the development of radicalism and violence in the city of Padang according to research figures, scientists, community leaders and also some students and the general public. This article is taken from the results of our interviews with several figures of Islamic mass organizations in Padang, scientists and the community, both in person (face to face) and via smartphone communication such as the Chairman of the MUI, Gus Rizal.
\end{abstract}

Keywords

Radicalism; intolerance; Padang city

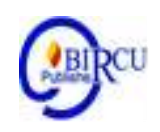

\section{Introduction}

The meaning of radicalism actually, in terms of language comes from the basic word radix which means tree roots or medasar thinking, to the principle. The meaning of the word, can be expanded, become a strong grip, belief, creator of peace and peace. Radical means more objective. So, people who think radically mean to have a more detailed and deep understanding, like a strong tree root, and determination to maintain their beliefs. This understanding, seemingly uncommon, creates a distorted impression in the community. Radicalism can be interpreted positively, namely renewal, improvement and a spirit of change towards goodness. It is hoped in the life of the nation and state of radical thinkers as a supporter of long-term reform. Thus the meaning of radicalism can be developed, into a perspective or way of thinking of someone who wants quality improvement, improvement, and peace in a multidimensional environment, so that all levels of society can live in harmony and peace. (Zaini and Abdul, 2020)

Radicalism and intolerance in Padang originated from the Padri incident. The Padri War occurred in West Sumatra in the Pagaruyung kingdom from 1803 to 1838 AD. This war was motivated by religious issues, although in the end it turned into a war against the Dutch colonialists. The word Padri is taken from the word Pidari or Padre, which means clerics who are always dressed in white. Therefore the padri movement group always wore white robes, in contrast to the indigenous people who liked black clothes. Some argue that they are called Padri because the Padri leader is a Padari himself. The people of Pedir then departed for the pilgrimage to Mecca via the Aceh port of Pedir According to Saifullah and Sufriyono.

The aim of this Padri is actually to improve the condition of the Minangkabau people, to invite them to do good deeds according to Islamic teachings, namely based on the AlQuran and Hadith. This movement was accepted happily by the ulama, even though it faced challenges from the adat community.

Because these two groups are opposing, where the adat group remains steadfast in maintaining the customs in their area and the Padri wants to control the adat community on pure Islamic teachings by force, there is a conflict between the Minang people. However, the 
Indigenous people lost and in the end they asked for Dutch help, causing the conflict to develop and burn the Netherlands.

The war between the Padri and the Indigenous people took place between 1803 and 1821. This occurred when 3 people returned from Mecca to perform the hajj. They are $\mathrm{H}$. Poor from the beach, H. Sumanik, Eight Cities, and H. Piabang from the Tanah Datar area. In Saudi Arabia they accepted the Wahabi doctrine, because at that time Wahabi was in a state of triumph. Basically they became an extension of Wahabi teachings in Minangkabau and called themselves the Padri group.

The Padris strongly oppose bad habits that develop and spread among indigenous peoples such as gambling, cockfighting, marijuana, drinking / drinking, tobacco, betel nut, and customary laws that are considered to violate religion such as matriarchal in terms of inheritance. Because this movement was considered to be coercive and violent, the Wahabi movement was referred to by Supriono as the initial movement of radicalism. Indeed, initially this dispute would be resolved peacefully, but because there was no agreement, Tuanku Nan Renceh invited the Padri group to resolve it with violence so that a civil war broke out between the Padri and the indigenous groups.

The first Padri War took place in Kotalawas. Furthermore, it extends to other areas. Initially the Paderi led by Datuk Bandaro attacked the Adat people led by Datuk Sati. Then Datuk Bandaro was poisoned and died and the Padri was led by Muhammad Syahab (Pelo (Pendito) Syarif. This Pelo Syarif is known in history as Tuanku Imam Bonjol. Called Tuanku Imam Bonjol because he lives in Bonjol. He is the son of Tuanku Rajanuddin. Originating from Kampung Padang Bubus, Tanjung Bungo, the Alahan Pajang Valley area.

The Padri won and since 1815 the position of the Indigenous people was getting weaker and even the Minangkabau royal family died in Tanah Datar. As a result, the Indigenous people (rulers) and the remnants of the royal family who were still alive asked the British for help (at that time under the leadership of Raffles). However, because the British handed over West Sumatra to the Dutch, the Indigenous people asked for Dutch help. This assistance was accompanied by a promise of compensation for the Dutch to control all of Minangkabau. This agreement was signed by 18 February 1821Sultan Tangkal Alam Bagagarand the Netherlands. This golden opportunity was taken by the Dutch to expand their colonies in West Sumatra.Consequently, the Dutch considered it a sign of surrendering to the Pagaruyung KingdomDutch East Indies, and finally the Dutch appointed Sultan Tangkal Alam Bagagar as Regent of Tanah Datar.

The leaders involved in the Padri War, Civil War were Datuk Bandaro, Datuk Malim Basa, Tuanku Imam Bonjol, Tuanku Pasaman, Tuanku Nan Renceh, and Tuanku Nan Cerdik from Padri and the Adat people led by Datuk Sati.

According to Tuanku Imam Bonjol's autobiographical notes, which he wrote himself, there is a statement containing his regret for the atrocity of Wahabi Paderi. This paper is the first autobiographical literary work in Malay and was kept by the descendants of Imam Bonjol and then published in 1925 in Berkley and in Padang in 2004. Whether this is true or not the author still questions it. 


\section{Review of Literature}

\subsection{Revolutionary Government of the Republic of Indonesia (PRRI)}

According to Saifullah, the PRRI movement was also part of the Radical movement which emerged in Padang in 1949, 4 years after the proclamation of RI independence. PRRI stands for the Revolutionary Government of the Republic of Indonesia, and Permesta stands for Perjuangan Semesta or Perjuangan Rakyat Semesta. This rebellion existed at the time of the formation of the United Republic of Indonesia (RIS) in 1949. The cause of the emergence of this movement was due to dissatisfaction with the central government's policy of shrinking the Bull Division to just one brigade. In fact, this discontent has also emerged in various regions such as Sumatra and Sulawesi regarding the allocation of the development budget set by the central government plus economic pressures and the low welfare of soldiers and society.

PRRI then formed the Struggle Council, did not recognize the Djuanda cabinet and also formed the PRRI cabinet. On January 19, 1958, military and civilian figures held a meeting at the Dareh River, West Sumatra which produced a statement "Jakarta Charter" demanding that President Soekarno be willing to return to the constitution and remove all consequences of actions that violate the 1945 Constitution and prove his willingness by words and deeds.

After the center rejected the above request, on February 15, 1958, Lieutenant Colonel Ahmad Husein proclaimed the establishment of the Revolutionary Government of the Republic of Indonesia (PRRI). Prime Minister Syafruddin Prawiranegara. PRRI also received support from PERMESTA and the local people so that this movement was called PRRI / PERMESTA.

Then the Central Government launched a joint military operation called Operation Merdeka, under the command of Lieutenant Colonel Rukminto Hendraningrat. This joint operation was great because PRRI was considered to have a modern US-made weapon capable of shooting down the Revolutionary Air Force (Aurev) aircraft carried by Allan L. Pope, a citizen of the United States. However, the PRRI / Permesta rebellion was resolved in August 1958, only lasted about 6 or 7 months and then in 1961 the government opened the opportunity for the remaining members of Permesta to return to the bosom of the Republic of Indonesia.

According to Saifullah, the PRRI was not commanded by the Padang people but by the Bataks, namelyLieutenant Colonel Ahmad Husein. It's just that he lives in West Sumatra. This was used as justification by him that basically Minang people are critical, even though it is difficult to carry out acts of terror because they are considered detrimental.

Meanwhile, according to Adri Febrianto, one of the UNP lecturers who is currently completing his doctoral study at UI, said that after the PRRI there was never another radical movement in Padang. In fact, the PRRI movement actually did not last long and was not fully supported by the Padang people and at the same time became a valuable lesson for the people of West Sumatra. 


\section{Discussion}

\subsection{Radicalism and Intolerance According to Figures, Ulama and Researchers in the City of Padang \\ Among those we interviewed and their opinions are:}

\section{a. Saifullah}

$\mathrm{He}$ is one of the professors on duty at the Faculty of Adab and Humanities, UIN Padang. He is also the former head of the CenterCountering Radicalism in UIN Padang. The results of our interview with him, the researcher found several analyzes. He saw more from the ethnology point of view that it was impossible for the Padang people to become the perpetrators of terror because they always thought before doing anything. They always question what is the benefit of doing terror, the advantages and disadvantages. However, the Minang people can become provocateurs or orators who lead to radical actions.

According to him, Minang people can become provocateurs of radicalism because in general Minang people work as trade, politics, scholars and writers. Minang people will never be a successful general even though they like to be intelligence, but he must be a successful politician, a scholar, trader, and writer from the past until now. Because Minang people usually like to talk, he is a good communicator and also a good thinker but he is usually not a good executor. If radicalism has ever emerged, I think the Padang people can only be good instigators. Therefore, according to him, Minang people can be good provocateurs, but Minang people are unlikely to be suicide bombers. According to him, when a Minang person wants to commit a suicide bombing, he looks like a trader. He will calculate how much he has to sit here, lay down here lose or gain. Usually, the character of the Padang people is calculated, if from 8 in the morning, how much profit can they be made and if at 9, how much is the profit until they reach the details. The character and culture of the Minang people who are traders are right, he said.

Because he was destined to become a trader, there was no way he could do something without calculating how much he lost. Therefore, according to him the Padang people tend to be materalism. The characteristic of the Padang people who tend to be materialisticindividualism is what makes the Padang people less united so that no Padang people have a large company that connects the Padang people to the Padang people. The character of the Padang people is a good single player, therefore there are field traders everywhere, but small is never big and many branches because they are always not united.

According to him, in terms of unity, especially family unity, in terms of social, the Padang people can unite, but in trade, they are still competitive. According to him, it is easier to unite field traders in social terms than to bring together Padang people who are special traders. So when talking about radicalism I think Padang people everywhere can be involved but in the position of provocateurs or planners, but if they are suicide bombers or terrorists, according to him, it is impossible. Even though there are 70 angels lure, surely the people of the desert still think; is it possible that 70 Angelies are correct and will be received.

For this reason, according to him, in all terrorist cases, if we read in the media, all terrorists in Indonesia we will not find Padang people, except at the level of provocateurs or designers. If stirring up people or inciting people from the Padang can do it well, but at the level of execution usually the Padang people stay behind. Whether this can be considered bad character, maybe not good. According to him, this has more to do with the mainset economy of the Padang people. Although there may be political factors, this is not dominant. If it is called high politics, the most correct, according to him, is the Padang people, as the proverb 
of padang outside wants, inside wants, over wants, under wants, on tempi na diate. Tempi na diate means that he doesn't want to be a soldier.

According to him, if the Padang people want to be a sweeper, then he will think that one day he will be the manager of the sweepers and then he will be in charge of all the sweepers. The prairie man will not be his subordinate forever. According to him, it is impossible for the Padang people to be found as subordinates forever. They always think that one day they are subordinate / managed, then the second they have managed people, the third is the driver or the boss. If this is not possible he will definitely come out. So when we analyze with the ethnic character shortener to see cases of radicalism, the Padang people will not be executors.

According to him, some of the radicals who had died in Padang were only provocateurs, he arranged it, he brought people together and he instigated people who wanted to flare up but after turmoil usually the Padang people were on the back line, just like starting from the jihad command, the Javanese were the perpetrators in paddock. Several months ago someone also tried to burn Dasmaraya, the Dasmaraya police station was a Javanese who was a transmigrant but not a Padang person.

If the Javanese, according to him who also lived in Jogja, know a little about the character of the Javanese, if the boss said or Kiai word or conscience goes forward, then nothing will stop him. He will go forward not much in consideration. If the Padang people always have a lot of consideration, so you will read the names of the provocateurs, even though there are Padang people, but according to him, we will not find them for executors. He did not say that Padang was clean from terrorism, but the character of the Padang people would only place them in the position of provocateurs and conceptors, not perpetrators or executors. According to him, the 60s were the same and if we read the history of political elements, according to him the Padang people were also in front of independence. including independence figures who in his opinion about $60 \%$ were Padang people. According to him, when other people were not literary literate, Padang people were already literary, when people started politics too and were still planning to advance politics, these Padang people had become political figures. So therefore terrorism can be seen from the ethnological approach, the character of the Padang people will be difficult to find to be the perpetrators or executors who are at risk.

He is also criticizing the Padang ethnicity, which tends to be materealist and hedonistic. So for these things of terrorism, no one from Padang wants to do it, but when in the mosque there are provocateurs shouting Allahuakbar, usually the Padang people are always at the front.

If it is related to the Padri war, according to Sapriyanto, this problem is the same as the context of the PRRI war which lasted only 3 years. It was declared 1958 and 1961 was over. According to him the Padang people did not dare to fight, were not good at war, but to fight the central army, he was able to give command, but the one who fought was Colonel Simbolon. The symbolic war, but for the PRRI Ahmad Husein declaration. So those who declared war were the Padang people, but for war other people were ordered so that PRRI was for the shortest rebellion in West Java. In other areas the rebellion could last for 15 years, while in Padang it was only over 3 years. Padang people can rebel and can fight. We Padang people are the most critical, don't like the term uwo what teachers, superiors, bosses say. 


\section{b. Sufriyono}

According to Sufriyono: The Wahabi salafi sect is also radical. However, salafi radicals are in the form of cultural and structural radicals. This is because the salafi wahabi think that only their sect is correct and others are not true. From a radical cultural perspective they do not want to join with others, they tend to isolate themselves and only join their own congregation.

They also don't want to be called an organization because they tend to be antiorganization. However, until now the salafis have never committed radical acts in the form of terror, it is still only at the cultural level and only as a verbal claim. According to Sufriyono, this flow is also anti-tarikat. In Payakumbuh, the results of his research, he said, are between naqsabandi and salafis, semi-salafis like MMI (Indonesian Mujahidin Council) which have the same ideology as salafis and are also anti-tariqat. The radicals they display are still in the form of threatening violence, for example; MMI and salafis in their lectures preach the tarikat, sometimes they say we will burn the radio later, because salafis say that the tarikat are a disease of the people and so on.

According to Sufriyono, tasauf and tarikat are part of the realm of Islam, not a disease as considered by the salafi Wahabi. Salafis consider illness due to the jargon of heresy. There are 3 scientific colloquiums served by salafis, namely: the science of kalam, tasauf and philosophy. That's why they forbid all three.

Sufriyono examines the salafi in terms of their social movements, what kind of ideology they have, how they spread their ideology, what media are used, meaning the patterns of their movements, if for me the patterns of their movements are violent but have not used violence that kills, but still not in accordance with it is still in the culture and structural, not yet a direct bond, that's what I know. If violent radicalism tends to action and terror, if MMI they have da'wah in the field, where immoral places like MUS, dating places, they move there but they also face challenges from groups there they have gangs that defend the group it has clash and complexity too, right.

This clash took place at MUS (tourist destination wrap). MMI often does socialization. It doesn't have the law, it should be like that. "If MMI does direct activities, if salafi to my knowledge there are no such thoughts, it is still in cultural and structural sectarianism," said Sufriyono.

Salafis always deny other understandings apart from them until Muhammadiyah is denied by them, not only NU but also tarikat. However, in the territory of the tarikat they cannot enter, for example the Pariaman area, the territory of the satria order, the region of 50 cities and others. In summary there are 8 tarikat areas in West Sumatra. Those groups cannot enter because that is the enemy and that person cannot be entered by the group. Before the West Sumatra region was divided, there were also many tariqats. Even though some people say that it is anti-tariqat in West Sumatra, it turns out that a lot of it is.

In West Sumatra the largest and most followers are Naqsabandiah and Satariah. Qadiriyah mostly in coastal areas. If Bukit Tinggi is mostly Naqsabandiyah and Satariyah. One of the figures is Uust Safrudin, who is Satariyah.

According to Sufriyono, the origin of violence started from the history of Padri. This is the dark history of Sumbar, the Padri war where there was a bloody conflict between the Minang Islam and Islam, as Hilter mentioned the Islamic vs Islamic jihad. Muslims are divided. The results of negotiations between Padre's radical groups and traditional groups or tharikat groups.

According to Sufriyono, the salafi movement is one of the Islamic identities that want to revive the Padri movement. He did not know in detail what the Padri preaching wanted. The preaching of Hajj Sumani, the poor Hajj in Padang has started to sink. Information about 
the Salafi movement can also be obtained from figures in West Sumatra such as Ust Elfi Syam who owns the West Sumatra Darul Iman Foundation.

Darul Iman has institutions ranging from TK IT to Higher Education. Salafis in Padang also vary. There are those who are somewhat moderate, easier and there are salafis who are stiffer. Salafi models like this are very selective and do not want to change at all. For them democracy is bid'ah. But this Salafi under the leadership of ust Elfisyam is more moderate, he chooses people who are as manhaj as him like PKS. Even though they did not accept democracy, they chose PKS because PKS was considered Salafism, close to their ideology.

In Padang there are also Darul Hadis salafi, but they are not well developed. Perhaps it was because of the low level of moderation that the Darul iman Foundation was more developed than the Darul Hadith.

According to Sufiyono MMI, Salafis and HTI do not commit structural violence, but cultural violence. This is because the violence they do is not directly in the form of terror but in the form of cultural action. MMI can be said to have carried out direct cultural violence, for example, everything they judge is not in accordance with sharia (according to them), so they claim this is not sharia, so it must be obliged. Even verbally, the Mujahajidin Council sometimes used harsher words like we are fighting in the form of action.

However, it is somewhat different from Salafis that it cannot be said to have committed structural violence directly, because salafis only talk. According to Sufriyono, Salafi is still at the level of speaking out, this is a bid'ah but it does not reach the dissolution event even though these words of heresy hurt other groups, especially tarikat groups, all of whom are considered as unhealthy by Salafis.

Salafis also do not come to takfir (kafir who is different). However, MMI got to takfir. This is where the difference between Salafis and MMIs. Salafis still claim to be different from preaching, but MMI comes to takfir, MMI even always considers a system or something they consider to be contradictory as a thagut (something that is worshiped by other than Allah). Salafis are engaging in their biggest conflict by refusing to accept the leader, even though the head is a traditional position in Minang. At one time, there was a tribal leader, the name of the payogodat tribe, who wanted to elevate the Salafi to the head, said the salafi leader is a bid'ah, the office holder is sinful. As a result, the indigenous group got angry so they said: are you a Minang person or not? if you are like that you are coming out of Minang / being expelled from adat.

MMI is also like that, when an MMI member gets married in Minang, one of the conditions is a leader. According to MMI's words they don't need customary requirements, they only need sharia requirements. Then the Minang people say yes if that is the case you are not civilized, then he was expelled from adat, expelled by the customary group, fined for adat, until now he is not recognized as a local resident. As well as being devout Muslims, Minang people are also strong customary holders. Salafists on average do not recognize adat, so one of the characteristics of their Minang people is lost and people like this tend to be considered radical.

\section{Conclusion}

Minang women in Minang are not the same as women in Java. They are relatively strong (customary). Don't tell me oo many Minang people in Jakarta have become vocation women, for example, maybe I didn't say no, but if she is relatively strong here there is no room for her to be free here so how do you then move from one place to another place in disguise and then actually he was carrying out a terrorism mission if he was a woman, it doesn't fit here, said Saifullah. 
Then who are the consumers? Where will he campaign? If he wants to recruit people here, only people from mosque to mosque, I think these mosques in Sumatra are not easy to accept lecturers. Many Padang people are critical and also preachers. Therefore, how can people accept lecturers who come that we don't know, but if in Java I know, as long as I am smart, I can definitely accept it in Java because I am being answered, yes, Javanese people for this religion are weak, so if it's radical, it's a little bit Hard, a little bit biting, usually people like it because the average Javanese is Islam so when something is a bit funny it makes him surprised he likes to bring the speaker.

According to him, there may be provocative preachers, but I am not saying no that the mosque is indoctrinated. If someone says that there is a mosque where the speaker is managed by the Mujahidin council, I don't think that's true either. In Padang the people here are critical. When I lecture, where if it's been two or three times it is usually replaced. People always want to change. People here don't want, for example, Aagym's lecturer to continue even though he is good. In Java, it is permissible, for example in West Java, it is permissible for Aagym's lecturer at the same age. People for life listen to Aagym's lecture. According to him here, it is different. One hearing, twice, is a little overhearing and the third time is not being heard again at all. This is because the character of the Padang people does not want to be in a place for long,

According to him, Padang women did not come to the radicals who asked to separate from the Republic of Indonesia, be hostile to RI, and disbelieve others. It's just that these Padang people are not easy to accept all kinds of preachers. The desert people are quite critical. Regarding the veil that was carried out by an English lecturer, not a religion lecturer, according to him, it was a radical attitude but not the BNPT version. According to him, there is nothing wrong with the veil. In general he agrees with the veil (happened to the lecturer on the high hill). According to him, he had a different opinion with the high hill lecturer who thought that the face of the lecturer could not be seen. What did he think his face was for? the important thing is to look at his brain, not his face. There are also those who say their English pronunciation is unclear.

The chairman of the MUI in Padang also tends to be radical in religion, although not in the BNPT's radical definition. It can be seen that the only MUI in the regions who dares to oppose the central MUI regarding Islam Nusantara, I think is the West Sumatra MUI. I have not heard that the North Sumatra MUI rejects Nusantara Islam or maybe the North Sumatra MUI does yes because North Sumatra NU is rather large, especially in South Tapanuli so if North Sumatra yes for Nusantara Islam I don't think it is a problem, I can understand it, he stressed.

If here Islam Nusantara is officially rejected by MUI and does not play the language geneng-geneng but with a frontal language spoken West Sumatra does not need Nusantara Islam, we already have local wisdom to bring together Islam and the culture of the local Islamic community, so we don't need Nusantara Islam. and NU's guidelines are sponsored. I think it's natural that West Sumatra is not accepted. So if you say radicalism in West Sumatra, yes, the proof is that our MUI chairman is radical, if not radical, how dare he say that.

Likewise, when our MUI chairman yesterday he was without talking about being appointed as a Jokowi volunteer, maybe he had this story to the second man without telling him that he was appointed as a volunteer advisor for Jokowi since he entered his name in the newspaper and was immediately furious, he immediately responded that it was not true. , that took my name and pronounced it tedenq aling-aling the people of West Sumatra, what do you think about this MUI if you refuse, don't be so hard, why will you later win Jokowi in West Sumatra, you just know that he is lucky and then you know the risks, don't be loud if you just 
refuse. if he does not reject it in his style now you know it, he told me. Our MUI is like that, it is typical of West Sumatra, if other people refuse, maybe you reject it secretly,

If other people talk from the BNPT aspect, I stand on the ethnicity of the Minang aspect of the Minang culture so for me if people here are radical, it can be understood that the Minang culture is that, if not so, don't ask for the BNPT version of the radical or the radical version like we are religious. According to him, the attitude of the chairman of the Padang MUI was radical but not yet radical according to the BNPT version.

According to him, the Rector of UIN Padang was also used as a volunteer just like the head of MUI, but our Chancellor said we are ASN, therefore we cannot volunteer, we cannot take sides until it is there. We don't use the word we demand who uses my name without my permission. Unlike the chairman of the Padang MUI.

Thus, in general, radical attitudes among men and also followed by women in religion are still quite developed, although Radicals here are not as radical as what BNPT means, but radical in the sense of implementing religion radically, rooted and strong.

\section{References}

Ali, Abdullah. (2007) .Metodelogi Penelitian dan Penulisan Karya Ilmiah. Cirebon : STAIN Press.

Alsa, Asmadi. (2003) .Pendekatan Kuantitatif dan Kualitatif, serta kombinasinya dalam penelitian psikologi. Yogyakarta : Pustaka Pelajar.

Azca, Muhammad Najib. (2011). "Yang Muda yang Radikal: Refleksi Sosiologis terhadap Fenomena Radikalisme Kaum Muda Muslimdi Indonesia Pasca Orde Baru." Pidato Dies Natalis ke 57.

Azra, Azyumardi. (2002). Konflik baru antar peradaban: globalisasi, radikalisme \& pluralitas. Divisi Buku Perguruan Tinggi, RajaGrafindo Perkasa.

Basrowi, Sukidin. (2002). Metode Penelitian Kualitatif, perspektif mikro. Surabaya : Insane Cendikia.

Bellah, Robert Neelly (1967). "Civil Religion in America". Daedalus, Journal of the American Academy of Arts and Sciences 96 (1): 1-21.

Berger, Peter. The Sacred Canopy. (1967)

Bobbio, Norberto. (1997). Left and Right: The Significance of a Political Distinction (translated by Allan Cameron), University of Chicago Press.

Bubalo, Anthony, and Greg Fealy. (2007). Jejak Kafilah: Pengaruh Radikalisme Timur Tengah di Indonesia. Mizan Pustaka.

Casanova, Jose. (1994). Public Religions in the Modern World. University of Chicago Press, Durant, Will, The Age of Faith; Simon \& Schuster (1980),

Durkheim, Emile (1976) The Elementary Forms of the Religious Life. London: George Allen \& Unwin (in French 1912, English translation 1915)

Effendi, Bahtiar, and Hendro Prasetyo. Radikalisme Agama. Jakarta: PPIM-IAIN (1998).

Effendy, Bahtiar, and Soetrisno Hadi. (2007). Agama dan radikalisme di Indonesia. Nuqtah.

Fananie, Zainuddin. (2002). Atika Sabardila, and Dwi Purnanto. Radikalisme Agama \& Perubahan Sosial. Surakarta: Muhammadiyah University Press \& The Asia Foundation.

Gauchet, Marcel. The Disenchantment of the World. (1985/tr. 1997).

Geertz, Clifford. (1993). Religion as a cultural system (archived 25 September 2007). pp. 87125 in Clifford Geertz, The Interpretation of Cultures: Selected Essays. London: Fontana Press.

Hasan, Noorhaidi. (2010). "Ideologi, Identitas dan Ekonomi-Politik Kekerasan: Mencari Model Solusi Mengatasi Ancaman Radikalisme dan Terorisme di Indonesia." Prisma. 
Hasan, Noorhaidi. (2009). "Multikulturalisme dan tantangan radikalisme." Merayakan kebebasan beragama, bunga rampai 70 tahun Djohan Effendi.

Hasani, Ismail, and Bonar Tigor Naipospos. (2012). Dari Radikalisme Menuju Terorisme, Studi Relasi Dan Transformasi Organisasi Islam Radikal Di Jawa Tengah Dan DI Yogyakarta. Jakarta: Pustaka Media.

Hasani, Ismail, and Bonar Tigor Naipospos. (2010). Radikalisme Agama di Jabodetabek \& Jawa Barat: Implikasinya terhadap Jaminan Kebebasan Beragama/Berkeyakinan.

Hobolt, Sara B.; Brug, Wouter Van der; Vreese, Claes H. De; Boomgaarden, Hajo G.; Hinrichsen, Malte C. (2011-09-01). "Religious intolerance and Euroscepticism". European Union Politics 12 (3): 359-379.

Koentjaraningrat. (1974). Kebudayaan, Mentalitet dan Pembangunan, pp. 137-142. Jakarta: Gramedia.

Lexy J. Moleong. (2007). Metodologi Penelitian Kualitatif Edisi Revisi. Bandung : Remaja Rosdakarya.

Marx, Karl. (1844). "Introduction to A Contribution to the Critique of Hegel's Philosophy of Right".

Max Weber. (1920). The Protestant Ethic and the Sprit of capitalism Montesquieu, 2012, , Book 11, Chapter 6, "Of the Constitution of England," Eletronic Text Center, Universirty of Virginia Library,Retrivied 1 August 2012.

England. (2012)." Electronic Text Center, University of Virginia Library, Retrieved 1 August.

Mubarak, M. Zaki. (2008). Genealogi Islam Radikal di Indonesia: gerakan, pemikiran, dan Prospek Demokrasi. LP3ES.

Parsudi Suparlan dalam Robertson, Roland (ed). (1988). "Agama", dalam Analisis dan Interpretasi Sosiologis, pp. v-xvi. Jakarta: CV Rajawali.

Pew Research Center (2012) The Global Religious Landscape. A Report on the Size and Distribution of the World's Major Religious Groups as of 2010. The Pew Forum on Religion \& Public Life.

Purnomo, Agus. (2009). Ideologi kekerasan: argumentasi teologis-sosial radikalisme Islam. STAIN Ponorogo Press.

Pusat Kajian Gender Wanita dan Gender Universitas Indonesia, Hak Asasi Perempuan, Yayasan Obor, Jakarta, 2007.

Qodir, Zuly. (2014). Radikalisme agama di Indonesia. Pustaka Pelajar.

Rawls, J. (1993/1996/2005) Political Liberalism (Columbia University Press, New York)

Rawls, John (1971). A Theory of Justice (Original ed.). Cambridge, Mass.: Belknap Press of Harvard University Press.

Ridwan, Nur Khalik. (2009). Doktrin Wahhabi dan benih-benih radikalisme Islam. Tanah Air.

Rinusu (Ed). (2007). Pengarusutamaan Gender Dalam Pembangunan di Indonesia: Teori dan Aplikasi. Jakarta: Kerjasama antara Kementerian Pemberdayaan Perempuan Republik Indonesia dan United National Development Program (UNDP).

Zaini, M and Abdul, H. (2020). Awareness of Medan Area Students in Demanding Against the Law of Drug Abuse, the Prevention of Radicalism and Terrorism. Budapest International Research and Critics Institute-Journal (BIRCI-Journal). P. 1239-1250 